\title{
The Utilization of History Module in the Development of Multiculturalism-Based Team Games Tournament Model to Improve the Bhineka Attitudes on 10th Grade Students in SMA Erlangga Pematangsiantar
}

\author{
Ahmad Fakhri Hutauruk ${ }^{1}$, Andres M. Ginting ${ }^{2}$ \\ ${ }^{1,2}$ History Education Study Program, Universitas Simalungun, Indonesia \\ fakhrispd@gmail.com
}

\begin{abstract}
This research is a development research that aims to produce alternative teaching materials in the form of a multiculturalismbased TGT model in increasing the diversity attitudes of students at Erlangga Pematangsiantar High School. The making of this module also aims to increase learning resources in the classroom and innovate learning media. The validation results of the module where the results of the material expert validation showed that the results of the material expert validation for the content component got an average score of 8.8 and 8.6 for the language component. The total average score for the two components was 8.7 in the "Highly Valid" category. The model's effectiveness test used a parametric statistical test, including the independent sample $t$ test and paired sample $t$ test. The results of the independent sample $t$ test show that the value of $t_{\text {count }}>t_{\text {table }}(3.101>1.711)$ so that $H_{0}$ is rejected and $H_{1}$ is accepted, which indicates that there is a difference in the mean cognitive scores of the experimental and control groups. In addition, the results of the independent sample $t$ test for the attitude scale show that the value of $t$ count $>t$ table $(2.527>1.711)$ so that $H_{0}$ is rejected and $H_{1}$ is accepted, which indicates that the diversity attitudes of students who use the history module are higher than students who use conventional models. The results of the calculation of the paired sample $t$ test for the cognitive domain show that the value- $t_{\text {count }}(-6,271)<-t_{\text {table }}(-1,711)$. $H_{0}$ is rejected and $H_{1}$ is accepted, so it can be seen that there is a difference in the mean score of the experimental group students before and after being treated. While the results of the calculation of the paired sample t test for the affective domain show that the value- $t_{\text {count }}(-3,698)<-t_{\text {table }}(-1,711) . H_{0}$ is rejected and $H_{1}$ is accepted, so it can be seen that there is a difference in the level of awareness of the diversity of the experimental group students between before and after treatment. Developing a multiculturalism-based TGT model history module is able to develop students' diversity attitudes.
\end{abstract}

\author{
Keywords \\ history module, teamgames \\ toumament; multiculturalism diversity
}

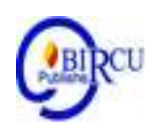

\section{Introduction}

History subjects received more time weight in the 2013 curriculum. The government began to look at history as an important subject. Especially if you look at the political condition of the people, which tends not to be separated from a sharp political identity. Mutual suspicion and intolerance can grow easily during the election process yesterday even up to now even though the political party is over. The young generation who are considered to be the nation's successors, must be equipped with an awareness of the principle of unity 
and multi-culturalism. History subjects teach the wisdom of figures and past events to the younger generation so that they are not easily divided and the dangers of national disintegration in the past. The nature that is happy with competition is a characteristic of the younger generation. This must be accompanied by a spirit of togetherness in diversity and an attitude of being ready to win and lose in our democracy. Through learning in schools, the role of the teacher is an important factor in providing a foundation for diversity in the younger generation, in this case the students. The teacher must facilitate the competitive attitude of students with the right model. However, the lack of teaching materials becomes an obstacle for teachers to run the Team Games Tournament (TGT) learning model which can be used as an alternative to developing a competitive attitude in a weakening multicuralism frame today.

History learning is an important and appealing subject. It has function and purpose as means to build student characters (Sirnayatin, 2017; Jumardi, 2015). Learning history must have wisdom values that are useful for embracing intelligence, shaping the attitudes, characters and personalities of students. This complies with 'The Minister of National Education Regulation Num. 22 Year 2006' regarding content standards. In that so, the conventional history learning, which only prioritizes memorization, needs to be changed into learning that gives students an understanding of the past and present, and their interactions with the future. (Afwan et al, 2020)

Based on the problems that arise above, in history lessons in schools it is necessary to develop teaching materials for teachers who support the national curriculum. One solution is a practical, creative, effective module that becomes a barrier for history teachers to be applied in the classroom. This module can make it easier for students to accept the concept of subject matter well and make the learning process fun and meaningful. So that it can help students to study on their own according to the national curriculum reference.

Based on the basic framework of the program, MGMP activities refer to the Regulation of the Minister of National Education of the Republic of Indonesia No. 16 of 2007 concerning qualifications and standards of teacher competencies, including educational competencies, personality competencies, professional competencies and social competencies. (Ramlan et al, 2020)

In addition, to make this happen, there is a Historical MGMP which is useful as a forum for discussion between subject teachers. At least, in one semester there will be two to three meetings. In addition to discussing learning materials, the forum also serves as a medium for exchanging ideas about the various obstacles, obstacles and limitations in each school unit regarding the aspects of the ongoing learning. The perceived limitation in teaching is the lack of supporting books. So far, they still use the 2013 Kemdiknas teacher and student books and do not use Student Worksheets (LKS) as before because they have made it a habit to discuss groups even though they are not optimal. Limited history of learning media (including the minimal use of multimedia-based media), and there is no History laboratory.

Education that is carried out from time to time is always changing in accordance with the times. Therefore, teachers as learning managers are required to be more creative and innovative in order to make learning outcomes more optimal. This is in accordance with the Law of the Republic of Indonesia Number 20 of 2003, Article 1 paragraph 19, concerning the National Education System (Sisdiknas) that education is a conscious and planned effort to realize a learning atmosphere and learning process so that students actively develop their potential to have spiritual, religious, self-control, personality, intelligence, noble character, 
and skills needed by themselves, society, nation and state. (Simorangkir and Sembiring, 2018)

Learning which refers to K13, SMA Pematangsiantar issued a policy that students are not allowed to bring mobile phones, Android devices, etc. to communicate, including in terms of learning (browsing) even in the school environment. This policy is a form of preventive action to prevent unwanted things, even though on the one hand access to communication and media is considered very important in learning if you look at the implementation of the 2013 Curriculum.

\section{Research Methods}

This study uses a Dick \& Carey development model. The model consists of 10 (ten) long procedures in the Dick \& Carey theory, making researchers make modifications adapted to Borg and Gall's theory of development. The design that will be developed after modification goes through 3 stages, namely: 1) problem identification, 2) design, 3) distribution. The researcher attempted to adapt the Dick \& Carey development model to Borg and Gall's development procedures.

At the product evaluation stage, the researcher only conducted a formative evaluation of the Dick \& Carey development model, the researcher used up to the ninth step, namely formative evaluation. Where a design, process or program has been deemed complete in a formative evaluation. This is in line with what Tegeh (2014: 38) explains in terms of component aspects, formative evaluation is directed towards certain parts of the evaluation object, while summative evaluation covers the whole. The following is a Dick \& Carey design modified with the Borg and Galls development procedure as seen in the image below:

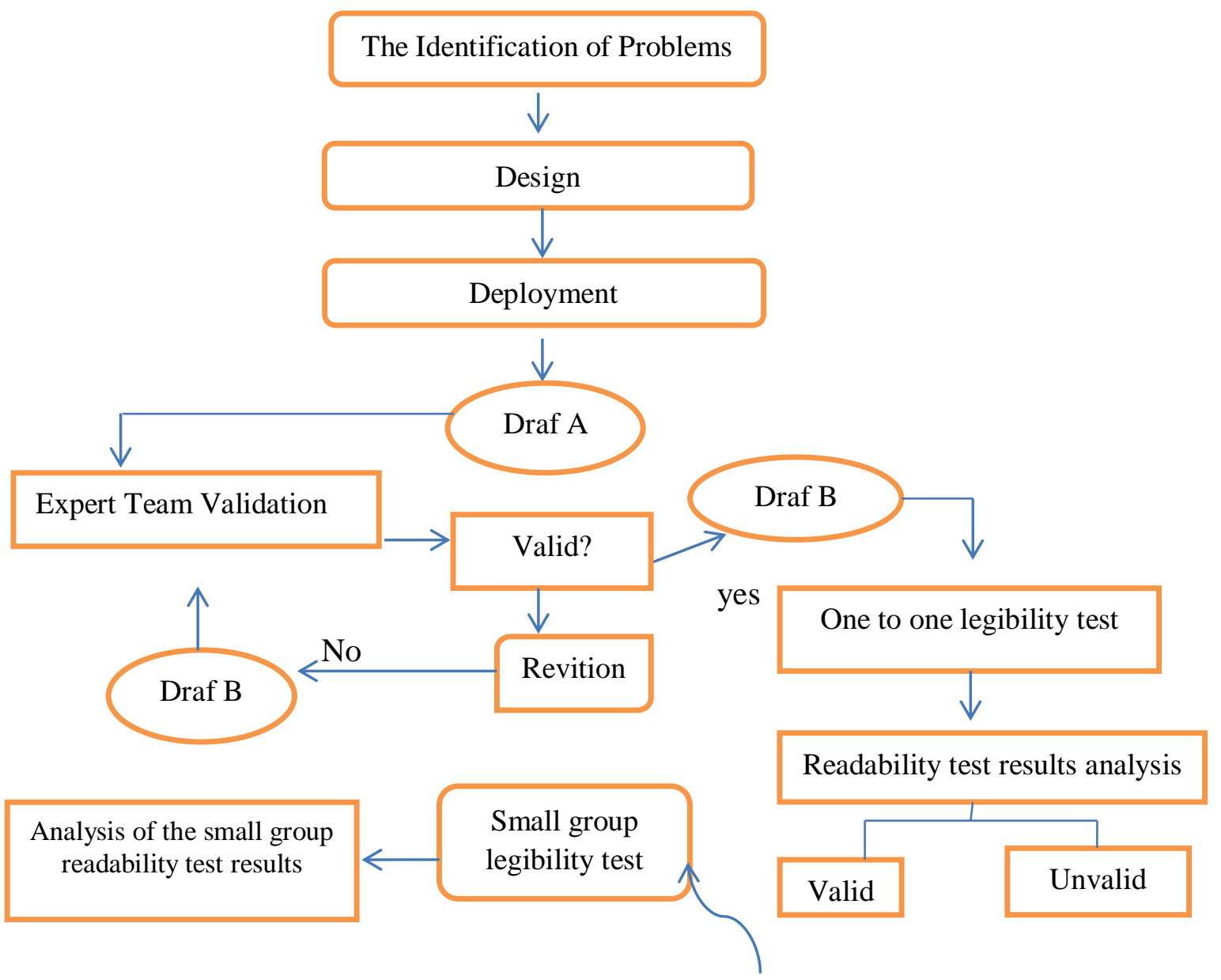




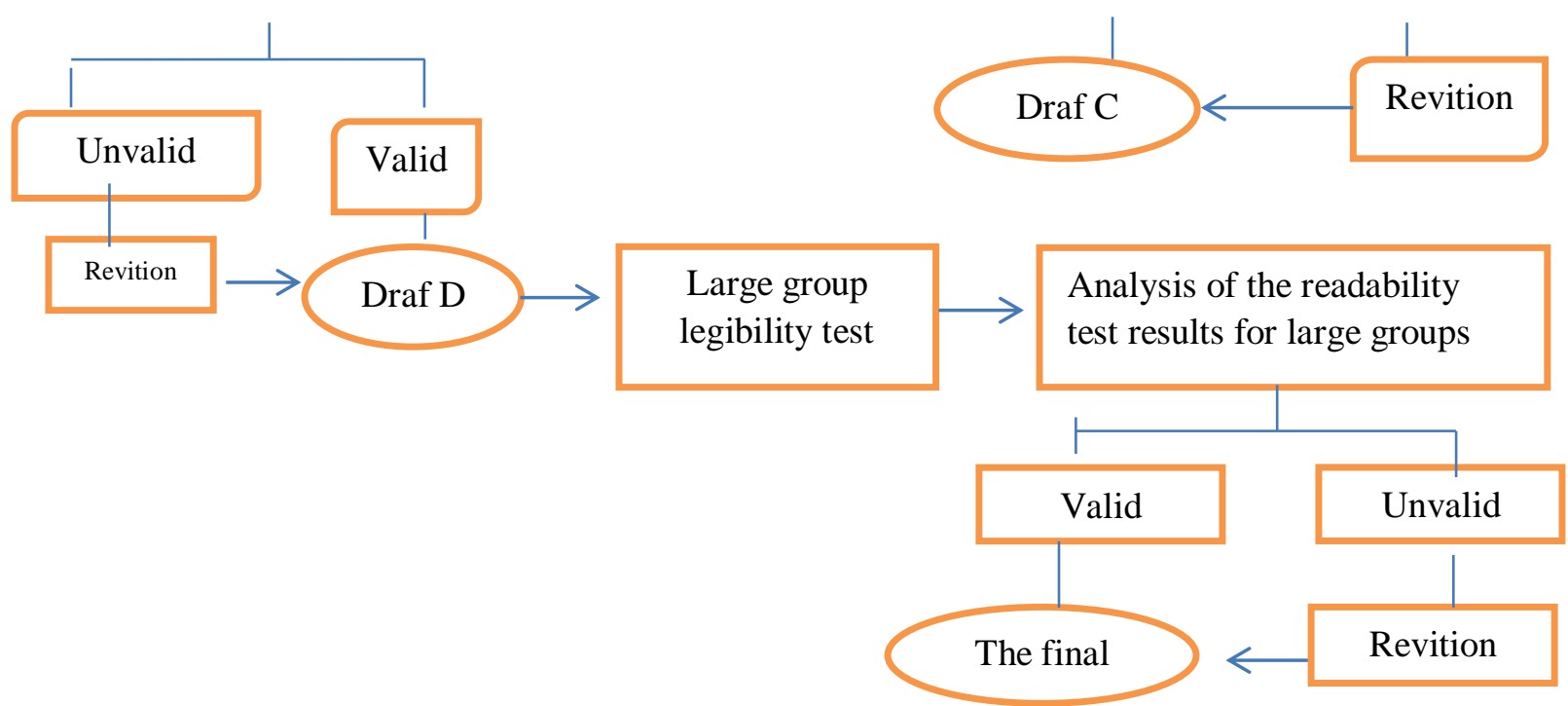

Figure 1. Research Procedure for Module Development of a multi-culturalism-based team games tournament learning model

The following is a table of media validity criteria which is used as a reference in this development research.

Table 1. Criteria for percentage of textbook assessment

\begin{tabular}{|l|l|}
\hline Achievement Level & Level of Validity \\
\hline $85,01 \%-100 \%$ & Very valid, or can be used without revision \\
\hline $70,01 \%-85 \%$ & Quite valid, or can be used but needs minor revisions \\
\hline $50,01 \%-70,0 \%$ & $\begin{array}{l}\text { Less valid, it is recommended not to use it because it needs } \\
\text { major revision }\end{array}$ \\
\hline $01,00 \%-50,00 \%$ & Not valid, or may not be used \\
\hline
\end{tabular}

Source: Akbar, (2015: 41)

\section{Discussion}

This section will present the results of research in developing the Historical Learning module in the development of the Multiculturalism-based TGT model. In general, the research findings will be broken down into three stages. First, a preliminary study consisting of research findings in the use of the multiculturalism-based history of the development of TGT modules that have been applied by teachers at Erlangga Senior High School Pematangsiantar. Second, namely the stages regarding the process of the history module development of the multiculturalism-based TGT development module. Third, test the learning module.

Educational product development in the research location must depart from a needs analysis. That is, the extent to which the level of school needs (teachers and students) is related to the products to be used in teaching and learning activities in the classroom. It is important to note that the development of this model is based on the needs of teachers and students in producing a conceptual framework for historical learning that adopts the values of local multiculturalism. Students are given information about the implementation of the History learning model in class. In general, they do not understand what is meant by the learning model. The researcher tries to explain in simple terms the concept of the model that will be applied in the classroom in the presence of certain procedures or steps. Researchers 
try to ask students what they want. Some students said that so far, history learning with the concept of group discussion sometimes took place, but they wanted to use video when learning in class so that it was not saturated.

Various descriptions presented in the needs analysis can be obtained as follows; first, it shows that the 2013 Curriculum supports the concept of local excellence or regional potential. Researchers studied the 2013 Curriculum documents by looking for Core Competencies and Basic Competencies to make adjustments to local themes that would be integrated with History learning. Second, not many students know the potential of their area (Pematang Siantar) from a socio-cultural aspect, especially in Pematangsiantar. Third, K13 requires students to have social skills by actively carrying out class discussions, so that each face-to-face learning History discussion must exist even though the reality has not been running optimally. Fourth, the need to help teachers find problems related to local issues which have relevance to the subject matter. Fifth, students need another learning atmosphere by inserting learning videos in teaching and learning activities in class so that students are not bored. Sixth, the need to instill a multiculturalism attitude at a simple level at the junior high school level such as mutual respect, accepting differences, consensus, participatory, and mutual cooperation.

Various descriptions are obtained from the needs analysis, so the development of a History learning model with material on the potential of local culture (Siantar City Multiculturalism) is needed as an alternative to History learning which aims to add new vocabulary of knowledge for students. Furthermore, this learning model can be perfected by the teacher by adjusting the various goals to be achieved.

This module departs from the analysis of the learning needs of teachers and students in schools. The need to raise local issues as an important study that is integrated with subjects will have meaning. Contextual local issues, coupled with the relevance of mapping subject matter in schools do not only have important value in terms of aspects of learning activities. However, as part of introducing (promoting) to readers about the cultural icons of each region. There are so many local wisdoms in Indonesia, it needs to be raised as part of the integration of the national culture which has a distinctive Indonesian personality. This learning model aims to develop students' multiculturalism attitudes.

It is necessary to note that the Pematangsiantar community is a society that lives in a variety of ways of embracing religion. Diversity can only be addressed through a deep appreciation, namely to appreciate that human nature is living in difference. So that accepting and respecting each other is a way to create a harmonious, safe, serene and peaceful life. The concept to be conveyed to students in this learning model is about human interaction in relation to religious symbolism, the concept of diversity; diversity of ethnic groups, cultures and religious systems, tolerance of worship as part of the multiculturalism of society, government policies as a legal basis in society, and tradition (local wisdom) as part of human interaction. Meanwhile, the products produced in this development research are combined learning steps between TGT learning through contextual, rational, and scientific approaches. Furthermore, the learning steps procedure will be elaborated through the Learning Implementation Plan and implementation in the field.

\subsection{Pretest and Posttest Results}

In this first trial activity, several obstacles were encountered, including student participation who was considered to be still minimal, it seemed that enthusiasm in learning was only dominated by a few students so that the discussion process was not going well, the reluctance of students who only wanted to group with friends who were close or have a match, Students, especially boys, joke around too much during discussions and presentations, 
because the first trial the teacher still seems difficult to divide the time in each stage of the activity. As far as the implementation of learning in the classroom, the positive appearance is seen only when watching the video. The students seemed really paying attention. The results of the discussion and recommendations with the teacher produced important points about how to activate students and strategies for further understanding the material by students about what the teacher said.

In this first scale test, besides aiming to determine the initial conditions for the implementation of the model along with the obstacles encountered, it also aims to find out students' responses to the model. The measurement used was the pre-test-post-test value instrument, the observation during the discussion, and the attitude scale questionnaire score (pre-post). Researchers compared cognitive abilities before and after treatment with the same subject, as well as whether there was a difference in the mean scores of the attitude scale questionnaire. The test statistics used include the Lilliefors / Npar Tests and Paired Sample T Test with the following hypotheses:

\subsection{Par Test}

Table 2. One-Sample Kolmogorov-Smirnov Test

\begin{tabular}{|ll|l|l|}
\hline & & Pre_ & Post__ \\
& & Questionnaire & Questionnaire \\
\hline N & & 24 & 24 \\
Normal Parameters ${ }^{\mathrm{a}, \mathrm{b}}$ & Mean & 71,00 & 72,54 \\
& Std. Deviation & 4,845 & 3,718 \\
Most Extreme Differences & Absolute &, 212 &, 119 \\
& Positive &, 212 &, 119 \\
& Negative &,- 142 &,- 093 \\
Kolmogorov-Smirnov Z & & 1,039 &, 584 \\
Asymp. Sig. (2-tailed) & &, 230 &, 885 \\
\hline
\end{tabular}

a. Test distribution is Normal.

b. Calculated from data.

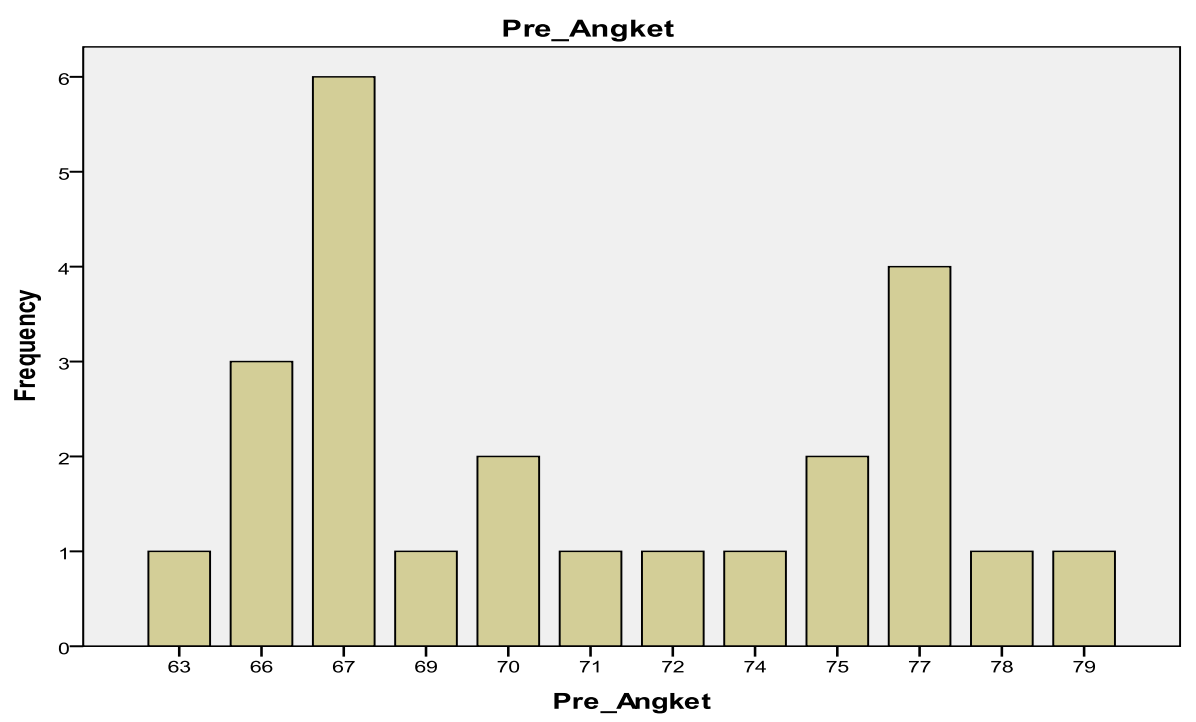

Figure 2. Pre-Questionnaire Score Bar 


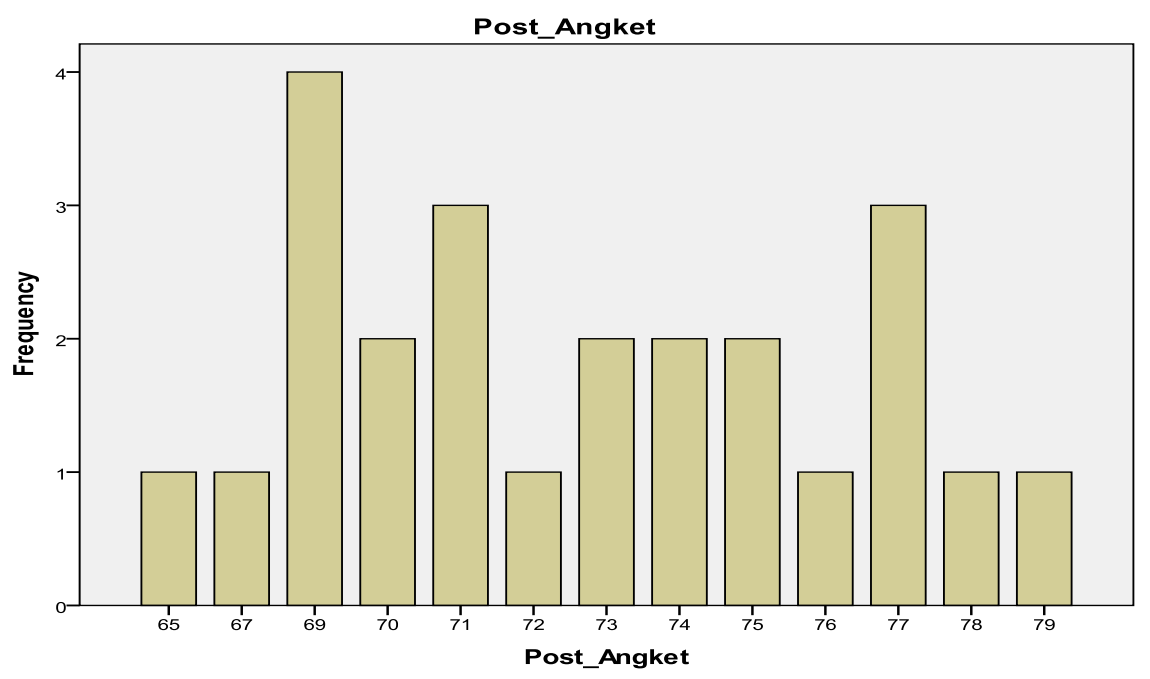

Figure 2. Post-Questionnaire Score Bar

Data is considered to be normally distributed if the statistical calculations yield a significance> 0.05 . Based on the calculations, the pre-questionnaire significance value was 0.230 and the post-questionnaire significance value was 0.885 . From these results it can be concluded that the data distribution is normally distributed. Furthermore, using the $t$ test which is intended to determine how much influence if each sample is given treatment. Statistical test using Paired Sample T Test with the reasons being compared only on one subject and two treatments. The calculation output is as follows:

\subsection{Uji T-Test}

Table 3. Paired Samples Statistics

\begin{tabular}{|ll|l|l|l|l|}
\hline & & Mean & N & Std. Deviation & Std. Error Mean \\
\hline Pair 1 & Pre_Questionnaire & 71,00 & 24 & 4,845 &, 989 \\
& Post_Questionnaire & 72,54 & 24 & 3,718 &, 759 \\
\hline
\end{tabular}

Table 4. Paired Samples Correlations

\begin{tabular}{|ll|l|l|l|}
\hline & N & Correlation & Sig. \\
\hline Pair 1 & Pre_Questionnaire \& Post_Questionnaire & 24 &, 919 &, 000 \\
\hline
\end{tabular}

Table 5. Paired Samples Test

\begin{tabular}{|c|c|c|c|c|c|c|c|c|c|}
\hline & \multicolumn{5}{|c|}{ Paired Differences } & \multirow[b]{2}{*}{$\mathrm{T}$} & \multirow[b]{2}{*}{ Df } & \multirow[b]{2}{*}{$\begin{array}{l}\text { Sig. } \\
(2- \\
\text { tailed })\end{array}$} \\
\hline & & Mean & $\begin{array}{l}\text { Std. } \\
\text { Deviation }\end{array}$ & $\begin{array}{l}\text { Std. } \\
\text { Error } \\
\text { Mean }\end{array}$ & \begin{tabular}{|l|}
$95 \%$ \\
Confid \\
Interva \\
Differe \\
Lower \\
\end{tabular} & $\begin{array}{l}\text { ence } \\
\text { lof the } \\
\text { nce } \\
\text { Upper }\end{array}$ & & & \\
\hline $\begin{array}{l}\text { Pair } \\
1\end{array}$ & $\begin{array}{l}\text { Pre_Questionnaire } \\
\text { Post_Questionnaire }\end{array}$ & $-1,542$ & 2,043 & 417 & $-2,404$ &,- 679 & $-3,698$ & 23 &, 001 \\
\hline
\end{tabular}


Based on these results, the $t$ value is -3.698 with a significance of 0.001 which is smaller than 0.05. So it is rejected and accepted, which means that there is an increase in the score of the student questionnaire before and after being given treatment.

From the results of the table data, the statistical test calculations were carried out using the Paired Samples T Test model. Before the calculation is carried out, because this type of model is parametric, the requirements must be taken by carrying out a normality test which aims to determine whether the data is normally distributed or not. The normality test uses the Lilliefors test model assisted by the SPSS version 19 program. The results of the calculation are as follows:

\subsection{Descriptive Analysis of Questionnaire Scores (Pre and Post) Attitude Scale Control Class}

Table 6. Descriptives

\begin{tabular}{|c|c|c|c|}
\hline & & Statistic & Std. Error \\
\hline \multirow[t]{13}{*}{ Pre_Questionnaire } & Mean & 67,25 & 1,246 \\
\hline & 95\% Confidence IntervalLower Bound & 64,67 & \\
\hline & for Mean $\quad$ Upper Bound & 69,83 & \\
\hline & 5\% Trimmed Mean & 67,31 & \\
\hline & Median & 67,50 & \\
\hline & Variance & 37,239 & \\
\hline & Std. Deviation & 6,102 & \\
\hline & Minimum & 56 & \\
\hline & Maximum & 77 & \\
\hline & Range & 21 & \\
\hline & Interquartile Range & 10 & \\
\hline & Skewness &,- 014 &, 472 \\
\hline & Kurtosis &,- 874 &, 918 \\
\hline \multirow[t]{13}{*}{ Post_Questionnaire } & Mean & 70,67 &, 861 \\
\hline & 95\% Confidence IntervalLower Bound & 68,89 & \\
\hline & for Mean $\quad$ Upper Bound & 72,45 & \\
\hline & $5 \%$ Trimmed Mean & 70,79 & \\
\hline & Median & 70,50 & \\
\hline & Variance & 17,797 & \\
\hline & Std. Deviation & 4,219 & \\
\hline & Minimum & 62 & \\
\hline & Maximum & 77 & \\
\hline & Range & 15 & \\
\hline & Interquartile Range & 6 & \\
\hline & Skewness &,- 318 &, 472 \\
\hline & Kurtosis &,- 430 &, 918 \\
\hline
\end{tabular}




\subsection{Questionnaire Score Normality Test (Pre and Post) Attitude Scale \\ Control Class X IPA}

Table 7. Tests of Normality

\begin{tabular}{|l|l|l|l|l|l|l|}
\hline & \multicolumn{3}{|l|}{ Kolmogorov-Smirnov ${ }^{\text {a }}$} & \multicolumn{3}{l|}{ Shapiro-Wilk } \\
\cline { 2 - 7 } & Statistic & Df & Sig. & Statistic & df & Sig. \\
\hline Pre_Questionnaire & 097 & 24 &, $200^{*}$ &, 965 & 24 &, 558 \\
Post_Questionnaire & 138 & 24 &, $200^{*}$ &, 954 & 24 &, 327 \\
\hline
\end{tabular}

a. Lilliefors Significance Correction

*. This is a lower bound of the true significance.

\subsection{T/ T-Test}

Table 8. Paired Samples Statistics

\begin{tabular}{|ll|l|l|l|l|}
\hline & & Mean & N & Std. Deviation & Std. Error Mean \\
\hline Pair 1 & Pre_Questionnaire & 67,25 & 24 & 6,102 & 1,246 \\
& Post_Questionnaire & 69,46 & 24 & 4,681 & 955 \\
\hline
\end{tabular}

Table 9. Paired Samples Correlations

\begin{tabular}{|ll|l|l|l|}
\hline & & $\mathrm{N}$ & Correlation & Sig. \\
\hline Pair 1 & Pre_Questionnaire \& Post_Questionnaire & 24 &, 952 &, 000 \\
\hline
\end{tabular}

Table 10. Paired Samples Test

\begin{tabular}{|c|c|c|c|c|c|c|c|c|}
\hline & \multicolumn{5}{|c|}{ Paired Differences } & & \multirow[b]{2}{*}{ Df } & \multirow[b]{2}{*}{$\begin{array}{l}\text { Sig. } \\
(2- \\
\text { tailed })\end{array}$} \\
\hline & Mean & $\mid \begin{array}{l}\text { Std. } \\
\text { Deviation }\end{array}$ & $\begin{array}{l}\text { Std. } \\
\text { Error } \\
\text { Mean }\end{array}$ & $\begin{array}{l}95 \% \\
\text { Confid } \\
\text { Interva } \\
\text { Differe } \\
\text { Lower }\end{array}$ & $\begin{array}{l}\text { ence } \\
\text { ll of the } \\
\text { ence } \\
\text { Upper }\end{array}$ & $t$ & & \\
\hline $\begin{array}{ll}\text { Pair } & \text { Pre_Q Questionnaire } \\
1 & \text { Post_Questionnaire }\end{array}$ & $-2,208$ & 2,187 &, 446 & $-3,132$ & $-1,285$ & $-4,948$ & 23 &, 000 \\
\hline
\end{tabular}

Based on these results, the $t$ value is $-4,948$ with a significance of 0,000 which is smaller than 0.05. So it is rejected and accepted, which means that there are differences in student questionnaire scores before and after being given treatment

The model effectiveness test can be seen from the statistical calculation of data through the SPSS application program, in this case using SPSS Version 19. To test the effectiveness, analysis prerequisite tests are needed, namely the Normality Test and Lavene's Variance Homogeneity Test. The results of the data normality test showed a significance value of X1 of 0.305 (post-test A) and Y1 value of 0.885 (post-questionnaire A). Whereas for X2, the score was 0.367 (post-test B) and Y2 was 0.327 (post-questionnaire B). The four values were obtained from the post-test and post-questionnaire statistical calculations of the two groups (experimental-control). This value is considered to be normally distributed because it has significance above 0.05. In addition, the value of the homogeneity test for the post-test (cognitive) was 0.5 . The significance value is above 0.05 , so it can be concluded that the 
cognitive value data achievements of students in the experimental group and the control group have the same variance.

The model's effectiveness test used a parametric type statistical test, including the independent sample $t$ test and paired sample $t$ test. The results of the independent sample $t$ test show that the value of $t_{\text {count }}>t_{\text {table }}(3.101>1.711)$ so that $\mathrm{H}_{0}$ is rejected and $\mathrm{H}_{1}$ is accepted, which indicates that there is a difference in the mean cognitive scores of the experimental and control group students. In addition, the results of the independent sample $t$ test for the attitude scale show that the value of $t$ count $>t$ table $(2.527>1.711)$ so that $H_{0}$ is rejected and $H_{1}$ is accepted, which indicates that the diversity attitudes of students who use the history module are higher than students who use conventional models.

The results of the calculation of the paired sample $t$ test for the cognitive domain show that the value-t count $(-6,271)<-$ table $(-1,711) . \mathrm{H}_{0}$ is rejected and $\mathrm{H}_{1}$ is accepted, so it can be seen that there is a difference in the mean score of the experimental group students before and after being treated. While the results of the calculation of the paired sample $t$ test for the affective domain show that the value- $t_{\text {count }}(-3,698)<-t_{\text {table }}(-1,711) . H_{0}$ is rejected and $H_{1}$ is accepted, so it can be seen that there is a difference in the level of awareness of the diversity of the experimental group students between before and after treatment. So, in conclusion, the history module is able to develop students' diversity attitudes

\section{Conclusion}

The History learning model carried out by teachers at Erlangga High School still refers to Teacher Centered characteristics. This statement is based on the dominant role of the teacher in giving lectures during the teaching and learning process. The lack of a reading culture by students which results in a lack of insight, and the not yet optimal learning innovation from the teacher, are two important factors that are fundamental reasons why classroom learning only takes place in one direction. However, that does not mean that the teacher never carries out discussion activities. Simple discussion activities in the teaching and learning process in class take place to meet the demands of the 2013 Curriculum, even though the reality is far from optimal and is rarely implemented. The discussion process can run quite smoothly if; 1) implemented in superior classes, 2) adequate infrastructure, and 3) implementing learning that can trigger student enthusiasm. The role of the Historical MGMP, which mediates teachers in exchanging ideas about learning in schools, has not been able to produce learning innovations that are able to assist teachers in transferring learning optimally.

The purpose of developing this learning model is to develop awareness of diversity which will be used as a guide in designing the development of models, learning tools, teaching materials, and learning media. The role of the teacher in this model is as a planner, designer, and facilitator in the teaching and learning process in the classroom. The curriculum used in the design of the model development is the 2013 Curriculum which leads to the learning activities of the Team games tournament, the delivery of values using the method of planting the values of diversity for students.

\section{Effectiveness of the History Module Based on Multiculturalism}

The model effectiveness test can be seen from the statistical calculation of data through the SPSS application program, in this case using SPSS Version 19. To test the effectiveness, analysis prerequisite tests are needed, namely the Normality Test and Lavene's Variance Homogeneity Test. The results of the data normality test showed a significance value of $\mathrm{X}_{1}$ of 0.305 (post-test A) and Y1 value of 0.885 (post-questionnaire A). Whereas for $\mathrm{X}_{2}$, the score was 0.367 (post-test B) and Y2 was 0.327 (post-questionnaire B). The four values were 
obtained from the post-test and post-questionnaire statistical calculations of the two groups (experimental-control). This value is considered to be normally distributed because it has significance above 0.05 . In addition, the value of the homogeneity test for the post-test (cognitive) was 0.5 . The significance value is above 0.05 , so it can be concluded that the cognitive value data achievements of students in the experimental group and the control group have the same variance.

The model's effectiveness test used a parametric type statistical test, including the independent sample $t$ test and paired sample $t$ test. The results of the independent sample $t$ test show that the value of $t_{\text {count }}>t_{\text {table }}(3.101>1.711)$ so that $\mathrm{H}_{0}$ is rejected and $\mathrm{H}_{1}$ is accepted, which indicates that there is a difference in the mean cognitive scores of the experimental and control group students. In addition, the results of the independent sample $t$ test for the attitude scale show that the value of $t$ count $>t$ table $(2.527>1.711)$ so that $H_{0}$ is rejected and $H_{1}$ is accepted, which indicates that the diversity attitudes of students who use the history module are higher than students who use conventional models.

The results of the calculation of the paired sample $t$ test for the cognitive domain show that the value-t count $(-6,271)<-$ table $(-1,711)$. H0 is rejected and H1 is accepted, so it can be seen that there is a difference in the mean score of the experimental group students before and after being treated. While the results of the calculation of the paired sample $t$ test for the affective domain show that the value- $\mathrm{t}_{\text {count }}(-3,698)<-\mathrm{t}_{\text {table }}(-1,711) . \mathrm{H}_{0}$ is rejected and $\mathrm{H}_{1}$ is accepted, so it can be seen that there is a difference in the level of awareness of the diversity of the experimental group students between before and after treatment. So, in conclusion, the history module is able to develop students' diversity attitudes.

\section{Acknowledgment}

Our gratitude goes to the Deputy for Strengthening Research and Development of the Ministry of Research and Technology / the National Research and Innovation Agency for funding the Beginner Lecturer Research (PDP) for the 2020 implementation year.

\section{References}

Afwan, B, et al. (2020). The Development of Digital Flipbook Media Based on the 5 Hours Battle of Kalianda upon High School History Materials. Budapest International Research and Critics Institute-Journal (BIRCI-Journal). P. 1003-1012

Akbar, Ali Sa'adun. (2015). Instrumen Perangkat Pembelajaran. Bandung: PT. Remaja Rosdakarya.

Muhammad \& Asrori. (2012). Psikologi Remaja Perkembangan Peserta Didik.Bandung: Bumi Aksara

Azwar, Saifuddin. (2010). Pengantar Psikologi Inteligensi. Yogyakarta: Pustaka Pelajar.

Borg, Walter R, \& Gall, Meredith D. (1983). Educational Research an information (4th ed).

New York: Longman Inc.

Daryanto dan Dwicahyo. (2014).Pengembangan Perangkat Pembelajaran. Yogyakarta : Gava Media.

Dimyati, et al. (2013). Belajar dan Pembelajaran. Jakarta: Rineka Cipta.

Direktur Jendral Pengembangan Mutu Pendidikan dan tenaga Pendidikan. (2008). Penulisan Buku tesk. Jakarta: Departemen Pendidikan Nasional.

Eggen, Paul D \& Kauchak (1988). Strategies for Teacher Teaching Content and Thinking Skills. New Jersey, Prentice Hall. 
Gardner, Howard.(2003). Multiple Intelligences : Kecerdasan Majemuk Teori dalam Praktek. Batam:Interaksara

Golemen, Daniel. (2007). Social Intelligence. Jakarta: PT Gramedia Pustaka Utama

Joyce Bruce. 2011. Model-Model Pengajaranedisikedelapan. Yogyakarta :Pustaka Pelajar

Ramlan et al. (2020). Based on the basic framework of the program, MGMP activities refer to the Regulation of the Minister of National Education of the Republic of Indonesia No. 16 of 2007 concerning qualifications and standards of teacher competencies, including educational competencies, personality competencies, professional competencies and social competencies. Budapest International Research and Critics Institute-Journal (BIRCI-Journal). P. 95-103.

Sanjaya, Wina. (2012). Perencanaan dan Desain Sistem Pembelajaran. Jakarta:

Kencana Prenada Media Group

Safaria,T.(2005). Interpersonal Intelligence. Yogyakarta: Amara Books.

Sagala. (2013). Konsep dan Makna Pembelajaran untuk Membantu Memecahkan Problematika Belajar dan Mengajar. Bandung: Alfabeta

Schunk, D.H. (2012).Teori-TeoriPembelajaran: PerspektifPendidikanedisikeenam. Yogyakarta: PustakaPelajar

Setyosari, Punaji. (2013). Metode Penelitian Pendidikan \& Pengembangan .Jakarta:

Kencana Prenadamedia Group

Simorangkir and Sembiring. (2018). Effectiveness of Helped Mathematical Learning Media of Lectora Inspire on The Number Sense Ability of Fifth Grade Students of Elementary School in Substrate Materials. Budapest International Research and Critics InstituteJournal (BIRCI-Journal). P. 352-358

Slavin E.R. (2010). Cooperative Leaning: TeoriRisetdanPraktik. Bandung: Nusa Media

Sugiyono. (2016). Metode Penelitian dan Pengembangan"Research and Development". Bandung: Alfabeta.

Tilaar, Har. (2004). Multikulturalisme: tantangan-tantangan global padamasadepan dalamtransformasipendidikannasional. Jakarta: LembagaManajemen Universitas Jakarta

Tobroni,et al. (2007). PendidikanKewarnegaraan :Demokarasi, Ham, Civil SocietydanMultikultural. Malang: Pusapom.

Trianto. (2010). Mendesian Model pembelajaran Inovatif-Progresif. Jakarta : Kencana 